\title{
Phosphorus dynamics in the North Pacific subtropical gyre
}

\author{
Karin Björkman*, Angie L. Thomson-Bulldis" ${ }^{* *}$ David M. Karl \\ Department of Oceanography, School of Ocean \& Earth Science \& Technology (SOEST), University of Hawaii, \\ Honolulu, Hawaii 96822, USA
}

\begin{abstract}
Phosphorus (P) dynamics were studied during several research cruises to Stn ALOHA and in the 'Climax region' of the North Pacific subtropical gyre (NPSG) in 1996-1997. The aim of this study was to: (1) investigate the coupled uptake and regeneration of inorganic phosphate $\left(\mathrm{P}_{\mathrm{i}}\right)$ and the production of dissolved organic phosphorus (DOP), (2) quantify the size of the biologically available $\mathrm{P}$ (BAP) pool, and (3) estimate the relative bioavailability of select organic $\mathrm{P}$ compounds to the natural microbial assemblages. At all stations, the microbial community was dominated by prokaryotes (>99.5\% of total cell numbers); Prochlorococcus spp. was the dominant pigmented group (>97\% by numbers), comprising 20 to $30 \%$ of the total prokaryotic population. Phosphate uptake rates were 3.0 to $8.2 \mathrm{nM} \mathrm{d}^{-1}$ (median $=3.5 \mathrm{nM} \mathrm{d}^{-1}$ ) and P pool turnover times ranged from 2 to $40 \mathrm{~d}$ (median $=9 \mathrm{~d}$ ). The BAP pool generally exceeded the $\mathrm{P}_{\mathrm{i}}$ pool, suggesting rapid turnover of at least a portion of the much larger DOP pool. The net production of DOP was approximately 10 to $40 \%$ of the net P uptake. Both the dissolved and the particulate organic matter pools were enriched in carbon (C) and nitrogen (N) relative to P, compared to the Redfield molar stoichiometry of 106C:16N:1P. The half-saturation constant, $K_{\mathrm{m}}$, values for $\mathrm{P}_{\mathrm{i}}$ uptake were higher than the ambient $\mathrm{P}_{\mathrm{i}}$ pool concentrations, and uptake rates were positively correlated with exogenous $P_{i}$ additions over the range tested $\left(P_{i}=25\right.$ to $\left.250 \mathrm{nM}\right)$. The bioavailabilities of exogenous adenine and guanine nucleotides were generally higher than other organic $\mathrm{P}$ compounds we tested. The net $\mathrm{P}_{\mathrm{i}}$ regeneration rate from nucleotides was up to 50 times higher than the net $P_{i}$ uptake rates, indicating a large potential for the regeneration of $P_{i}$ from specific organic compounds. These P pool dynamics observed in the NPSG are consistent with a microbial community currently under P control.
\end{abstract}

KEY WORDS: Phosphate uptake rates $\cdot$ Turnover rates $\cdot$ Bioavailable phosphorus $\cdot$ Bacteria $\cdot$ North Pacific

\section{INTRODUCTION}

More than a century ago, Liebig (1842) postulated that the one bioelement in the lowest total supply, with the lowest loading rate, or lowest availability relative to an organism's nutritional requirement ultimately would determine the productivity of the organism. In terms of ecosystem productivity, it is clearly of importance how various supply routes differ among the

\footnotetext{
*E-mail: bjorkman@soest.hawaii.edu

${ }^{* *}$ Present address: College of Education, University of Washington, Seattle, Washington 98195, USA
}

macro- and micronutrients, as it will affect the total inventories, and possibly the bioavailability of the respective bioelements. In oceanic waters nitrogen $(\mathrm{N})$ has conventionally been viewed as the nutrient most often limiting net organic production (Thomas 1966, Ryther \& Dunstan 1971, Eppley et al. 1973, Codispoti 1989). However, others have suggested that new production in marine environments may ultimately be limited by phosphorus (P) (Redfield 1958, Smith 1984), or trace elements (Falkowski 1997). This apparent contradiction arises from the implied role of biological fixation of dinitrogen $\left(\mathrm{N}_{2}\right)$ that could potentially relieve the ecosystem of N limitation (McCarthy \& Carpenter 1983, Tyrell 1999). 
The term 'new production' has most often been used to describe the portion of the net production fuelled by the influx of allochthonous nutrients as opposed to the portion that is supported by local nutrient regeneration (the new versus regenerated production paradigm; Dugdale \& Goering 1967). By current experimental application in field-based oceanographic studies, new $\mathrm{N}$ is generally equated to nitrate and regenerated $\mathrm{N}$ to the sum of ammonium and urea (Harrison 1990). However, atmospheric deposition of fixed $\mathrm{N}$ and gas exchange at the air-sea interface may significantly contribute to the supply of new $\mathrm{N}$ and other nutrients in the upper ocean (Buat-Ménard 1986, Duce 1986), in contrast to $\mathrm{P}$, which has negligible atmospheric exchange (Paerl 1993). The contribution from atmospheric sources of $\mathrm{P}$ to the total dissolved phosphorus (TDP) pool in the upper ocean has been estimated to less than $1 \%$ of the new $\mathrm{P}$ in the North Pacific gyre (Graham \& Duce 1979, Duce 1986, Chadwick et al. 1999). Furthermore, the open ocean habitats are too far removed to receive any significant amounts of $\mathrm{P}$ from other terrestrial sources, such as river discharge or land run-off. Consequently, the sources of new $\mathrm{P}$ are limited relative to those of $\mathrm{N}$ in the open ocean, and as long as these ecosystems support the growth of $\mathrm{N}_{2}$ fixing microorganisms, N should not limit primary production. Ultimately, other essential nutrients such as $\mathrm{P}$ may control oceanic productivity (Broecker 1974, Tyrell 1999).

Throughout the oligotrophic subtropical oceans, recent evidence suggests that the presence of both free-living and symbiotic diazotrophic organisms, including cyanobacteria (Trichodesmium spp. and Synechococcus spp.) and other unidentified $\mathrm{N}_{2}$-fixing Bacteria, may contribute significantly to new production (Mitsui et al. 1986, Carpenter \& Romans 1991, Karl et al. 1992, 1997, Letelier \& Karl 1996, Capone et al. 1997, 1998, Zehr et al. 1998). In the North Pacific subtropical gyre (NPSG), $\mathrm{N}$ derived from $\mathrm{N}_{2}$ fixation may contribute between 30 and $50 \%$ of the new $\mathrm{N}$ required to offset particulate $\mathrm{N}$ losses from the euphotic zone (Karl et al. 1997), and similar values have been estimated for the North Atlantic based on subeuphotic zone nutrient ratios (Michaels et al. 1996, Gruber \& Sarmiento 1997). These data suggest either that the quantitative importance of $\mathrm{N}_{2}$ fixation in open ocean nutrient cycles has been underestimated in the past or that recent habitat changes have selected for diazotrophic organisms in contemporary oligotrophic oceans, or both. Recently, Broecker \& Henderson (1998) proposed that the N:P stoichiometry of marine organic matter would shift between glacial and interglacial periods and that conditions favoring $\mathrm{N}_{2}$ fixation should lead to increased $\mathrm{N}: \mathrm{P}$ ratios. In the surface waters of the NPSG both the
C:P and N:P stoichiometries of the dissolved and particulate matter pools are well in excess of the classical Redfield ratios of 106:1 and 16:1 respectively (Karl et al. 1995, 2000b, Karl \& Tien 1997, Hebel \& Karl 2000). These observations, and others involving dissolved organic matter production (Karl et al. 1998), have been interpreted as evidence for $\mathrm{P}$ control.

In view of these recent reports, it has been hypothesized that the subtropical North Pacific has undergone a regime shift over the past few decades from a predominantly $\mathrm{N}$-controlled system, supporting a traditional eukaryotic food web, to an ecosystem where biogeochemical processes revolve around bacterial metabolism, and where production ultimately is controlled by the availability of P (Karl 1999, Karl et al. 2000a).

In a system undergoing such shifts on decadal time scales, it becomes paramount to resolve the changes in nutrient dynamics and community structure to be able to make relevant predictions about the productivity of Earth's largest biome. However, a persisting problem in nutrient dynamic studies is the analytical challenge to describe the ecologically relevant nutrient pools and fluxes among them. As long as we are unable to identify the chemical constituents of these pools, and to what degree they are available to the extant microbial communities, nutrient dynamics will remain poorly constrained. This restriction will consequently affect the interpretation of ecosystem productivity and carbon (C) flux.

By comparison to the $\mathrm{N}$ cycle, studies of $\mathrm{P}$ cycling in the NPSG are limited. Furthermore, relatively few tracer studies have been conducted in marine environments compared to work on the P cycle in freshwater ecosystems (Schindler 1977, Berman 1988, Tarapchak \& Moll 1990). There are some studies that have investigated uptake and regeneration of inorganic P $\left(\mathrm{P}_{\mathrm{i}}\right)$ in oceanic waters (Perry \& Eppley 1981, Cuhel et al. 1983, Sorokin 1985, Harrison \& Harris 1986, Cotner et al. 1997), and others focused on the utilization of the dissolved organic P (DOP) pool (Kuentzler 1970, Orrett \& Karl 1987, Björkman \& Karl 1994). However, it is currently uncertain to what extent analytically defined pools correlate to the biologically available P (BAP) pool, which is clearly the pool of greatest interest from an ecological and biogeochemical perspective.

In this study, conducted between July 1996 and August 1997 in the NPSG, the results from experiments performed to quantify $\mathrm{P}$ dynamics in the upper water column are presented. The primary objectives were to: (1) investigate the coupled uptake and regeneration of $\mathrm{P}_{\mathrm{i}}$ and the production of DOP, (2) quantify the size of the BAP pool, and (3) estimate the relative bioavailability of select organic P compounds. 


\section{MATERIALS AND METHODS}

Locations and seawater sampling. The majority of the seawater samples were collected at Stn ALOHA $\left(22.75^{\circ} \mathrm{N}, 158.00^{\circ} \mathrm{W}\right)$ during several Hawaii Ocean Time-series (HOT) cruises in 1996 and 1997. Additional experiments were conducted at a station within the 'Climax region' (Venrick et al. 1987) of the NPSG $\left(28.11^{\circ} \mathrm{N}, 155.36^{\circ} \mathrm{W}\right)$ in July 1996 and 1997 (Fig. 1). Seawater samples for incubation experiments and analyses were routinely collected from a depth of approximately $5 \mathrm{~m}$ using either Go-Flo or Niskin type polyvinyl chloride bottles, except on the July 1997 cruise, when a peristaltic pump fitted with Tygon tubing was used. The seawater was pooled into a large carboy prior to subsampling for organic and inorganic nutrients, chlorophyll a (chl a) and cell enumeration and population composition determinations by flow cytometry. Seawater for particulate carbon (PC), nitrogen

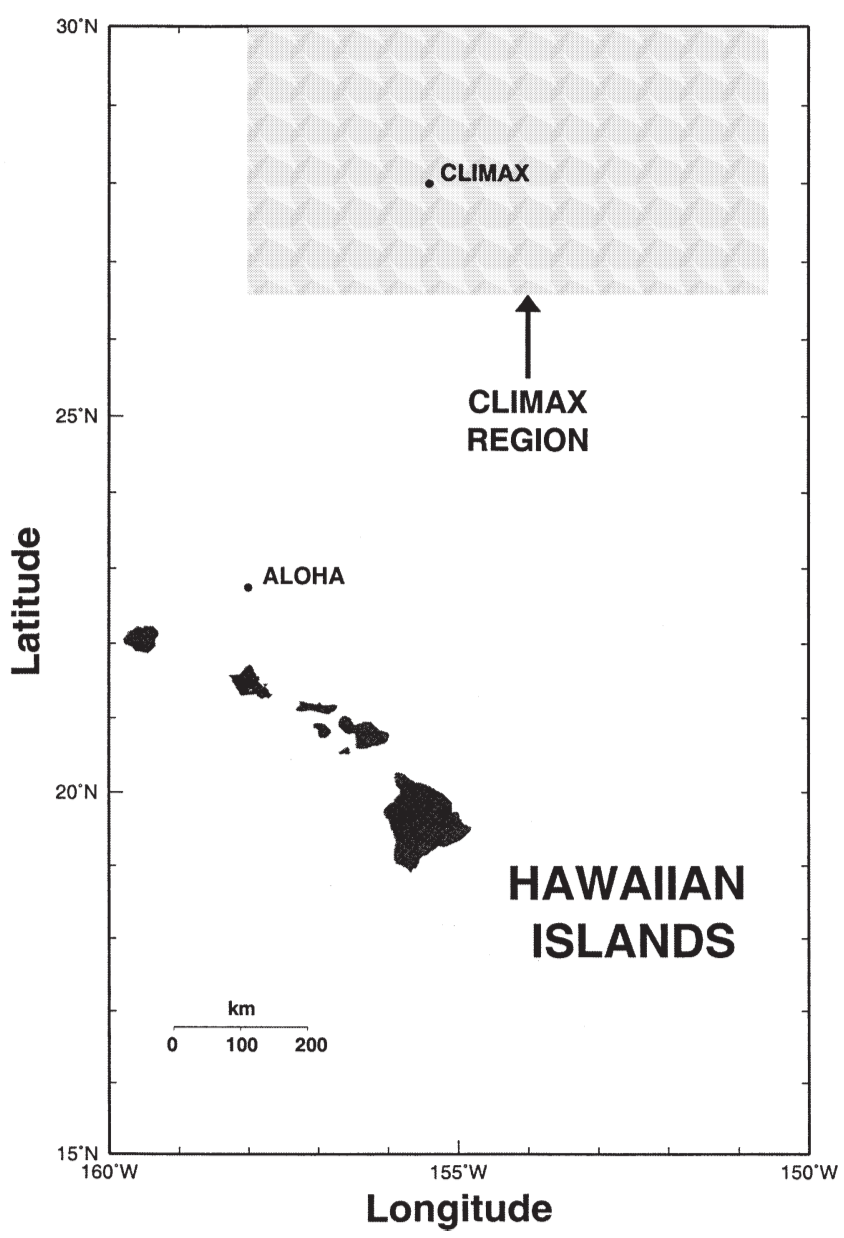

Fig. 1. Map of the sampling sites in the North Pacific subtropical gyre (NSPG). Stn ALOHA $\left(22.75^{\circ} \mathrm{N}, 158.00^{\circ} \mathrm{W}\right)$ and Stn Climax $\left(28.11^{\circ} \mathrm{N}, 155.36^{\circ} \mathrm{W}\right)$ within the Climax region (shaded box)
(PN) and phosphorus (PP) was collected separately, but within a few hours of the initial water collection.

Ancillary analytical measurements. Samples for nutrient determinations were placed into high-density polyethylene bottles and stored frozen (Dore et al. 1996) for later analysis of: (1) nitrate plus nitrite $\left[\mathrm{NO}_{3}{ }^{-}+\right.$ $\mathrm{NO}_{2}^{-}$, (2) soluble reactive phosphorus (SRP), (3) $\mathrm{P}_{\mathrm{i}}$, and (4) TDP and DOP concentrations (i.e., DOP $=$ TDP SRP). Samples for $\left[\mathrm{NO}_{3}^{-}+\mathrm{NO}_{2}^{-}\right]$were analyzed using an Antek model 720 chemiluminescence nitrogen oxide analyzer, according to the procedure described by Dore \& Karl (1996) after Garside (1982). SRP analyses were performed using the magnesium-induced coprecipitation method (MAGIC $;$ Karl \& Tien 1992), and $\mathrm{P}_{\mathrm{i}}$ analyses by the modified MAGIC procedure (Thomson-Bulldis \& Karl 1998). TDP concentrations were determined using the wet persulfate oxidation procedure (Menzel \& Corwin 1965) with modifications by Thomson-Bulldis \& Karl (1998). All P analyses were corrected for arsenate interference (Johnson 1971) and measured by absorption spectrophotometry $(880 \mathrm{~nm}$; Beckman DU 640). For particulate matter analyses (PC, $\mathrm{PN}$ and PP), 41 seawater was filtered through combusted glass fiber filters (Whatman GF/F) for PC/PN or combusted, acid-rinsed GF/F filters for PP (Karl et al. 1991). The PC/PN samples were analyzed using a Europa automated $\mathrm{C}$ and $\mathrm{N}$ analyzer. The PP concentrations were measured spectrophotometrically as dissolved P samples, following combustion $\left(450^{\circ} \mathrm{C}, 4.5 \mathrm{~h}\right)$ and acid hydrolysis.

For fluorometric chl a determinations, triplicate $150 \mathrm{ml}$ samples were filtered onto GF/F filters extracted in $100 \%$ acetone for $7 \mathrm{~d}$ in the dark at $-20^{\circ} \mathrm{C}$, then measured using a Turner model AU-10 fluorometer. Reagent chl a (\#C-6144, Sigma Chemical Co., St Louis, MO) was used as the primary standard.

For particulate ATP determinations, triplicate 0.5 to 1.01 samples were filtered onto GF/F filters and immediately extracted in $5 \mathrm{ml}$ boiling Tris buffer $(20 \mathrm{mM}, \mathrm{pH}$ 7.4). These samples were stored frozen for subsequent laboratory analysis by the firefly bioluminescence peak height method (Karl \& Holm-Hansen 1978). ATP concentrations were extrapolated to total living microbial biomass $\mathrm{C}$ by assuming a C:ATP ratio by weight of 250:1 (Holm-Hansen 1973, Karl 1980).

Samples for flow cytometry were preserved in paraformaldehyde $(0.2 \%$ final concentration $)$ and frozen in liquid $\mathrm{N}_{2}$ immediately after sampling (Campbell \& Vaulot 1993). The samples were stained with Hoescht $33342\left(1 \mathrm{\mu g} \mathrm{ml}^{-1}\right)$ and analyzed using a dual beam Coulter EPICS 753 flow cytometer $(250 \mathrm{~mW}$ 306 nm, 1 W 488 nm; Monger \& Landry 1993) The samples were analyzed for total microbial cell numbers and community composition as represented by non-pigmented prokaryotes (Bacteria and Archaea), 
Synechococcus spp., Prochlorococcus spp. and picoeukaryotic cells. These are operational definitions based on size, pigmentation and nucleic acid content. Cell numbers were extrapolated to biomass $\mathrm{C}$ using the following relationships: $10 \mathrm{fg} \mathrm{C} \mathrm{Cell}^{-1}$ for nonpigmented prokaryotes, $30 \mathrm{fg} \mathrm{C}^{\mathrm{C}} \mathrm{cell}^{-1}$ for Prochlorococcus spp., $100 \mathrm{fg} \mathrm{C}^{\mathrm{C}} \mathrm{cell}^{-1}$ for Synechococcus spp., and $495 \mathrm{fg} \mathrm{C} \mathrm{cell}^{-1}$ for pico-eukaryotic cells (Christian \& Karl 1994, Chavez et al. 1996, Zubkov et al. 1998). Further information on the HOT program sampling and analysis protocols can be found at the Website: http://hahana.soest.hawaii.edu/hot/hot_jgofs.html.

Radiotracer experiments. The rates of $P_{i}$ uptake and regeneration under a variety of conditions were determined using exogenous ${ }^{32} \mathrm{P}_{\mathrm{i}}$ as a tracer (orthophosphoric acid, carrier free; ICN Radiochemicals, \#64014 L). Seawater samples were dispensed into acid-washed, sample-rinsed, $500 \mathrm{ml}$ polycarbonate incubation bottles and, depending on the experiment, spiked with ${ }^{32} \mathrm{P}_{\mathrm{i}}$ to a final activity between 9 and $28 \mathrm{MBq} \mathrm{l}^{-1}$. The bottles were placed in an on-deck incubator maintained at ambient sea surface water temperature. A similar design was used in a variety of experiments, as described below.

During each HOT cruise a single dawn to dusk (10 to $14 \mathrm{~h}$ depending on season) ${ }^{14} \mathrm{C}$-bicarbonate in situ primary production experiment was conducted according to the methods described previously (Karl et al. 1996).

Light and dark uptake of ${ }^{32} \mathrm{P}_{\mathrm{i}}$ and production of $\mathrm{DO}^{32} \mathrm{P}$. To investigate the effect of irradiance on $\mathrm{P}_{\mathrm{i}}$ uptake, replicate sample bottles were incubated either in continuous darkness or under natural light conditions (day-night). A $100 \mathrm{ml}$ portion from each sample treatment (conducted in duplicate) was collected immediately after ${ }^{32} \mathrm{P}_{\mathrm{i}}$ addition and filtered through a $0.2 \mu \mathrm{m}$ polycarbonate membrane filter (Nuclepore) to serve as the time zero measurement for ${ }^{32} \mathrm{P}$-particulate activity. Subsequent samples were collected at various intervals, usually 4 to 6 times, over an 18 to $24 \mathrm{~h}$ period. The filters were placed into borosilicate scintillation vials for later liquid scintillation counting (LSC) and the $0.2 \mu \mathrm{m}$ filtrate was collected and immediately frozen for subsequent analyses of total SRP and DOP concentrations, and ${ }^{32} \mathrm{P}_{\mathrm{i}}$ labeled DOP $\left(\mathrm{DO}^{32} \mathrm{P}\right)$.

In related $\mathrm{P}_{\mathrm{i}}$ uptake experiments a sterile-filtered $(0.2 \mu \mathrm{m})$ phosphate $\left(\mathrm{KH}_{2} \mathrm{PO}_{4}\right)$ stock solution $(125 \mu \mathrm{M})$ was added to seawater samples to effect an exogenous $\mathrm{P}_{\mathrm{i}}$ addition of $25,50,75,125$ and $250 \mathrm{nM}$. The final $\mathrm{P}_{\mathrm{i}}$ concentrations were determined by laboratory analyses, as described above. The $\mathrm{P}_{\mathrm{i}}$ additions were made immediately after the ${ }^{32} \mathrm{P}_{\mathrm{i}}$ spike had been added. Subsamples were taken 4 times over a $12 \mathrm{~h}$ incubation period.

BAP experiments. Compounds investigated as potential P sources for microbial metabolism were obtained from the Sigma Chemical Company and prepared as
$2 \mathrm{mM}$ P stock solutions in sterile filtered $(0.2 \mu \mathrm{m})$ distilled water. Aliquots were stored at $-20^{\circ} \mathrm{C}$ to minimize hydrolysis. The compounds used were: glucose-1-phosphate (G-1-P; \#G-9380), glycerophosphate (GYP; \#G-6014), phosphoenol pyruvate (PEP; \#P-7002), ribulose-1,5-bisphosphate (RuBP; \#R-0878), adenosine5'-triphosphate (ATP; \#A-5394), guanosine-5'-diphosphate (GDP; \#G-8877) and ribonucleic acid (RNA; \#R-7125). The stock solutions were added to the incubation bottles immediately after the addition of the ${ }^{32} \mathrm{P}_{\mathrm{i}}$ to achieve a final concentration of approximately $250 \mathrm{nM} \mathrm{P}$. Unsupplemented seawater served as a negative control, and seawater with an addition of $\mathrm{P}_{\mathrm{i}}$ equivalent to that of the exogenous organic P treatments (250 nM P) served as a positive control for BAP. To measure ${ }^{32} \mathrm{P}$ particulate radioactivity, triplicate $10 \mathrm{ml}$ subsamples were collected at approximately 4 to $6 \mathrm{~h}$ intervals over a $24 \mathrm{~h}$ incubation period and were filtered onto $0.2 \mu \mathrm{m}$ polycarbonate filters (Nuclepore). Unfiltered subsamples were also collected for total ${ }^{32} \mathrm{P}_{\mathrm{i}}$ radioactivity. Following the $24 \mathrm{~h} \mathrm{sam-}$ pling period the remaining seawater was collected for endpoint SRP and TDP analysis. An identical set of incubations without the ${ }^{32} \mathrm{P}_{\mathrm{i}}$ radiotracer was run in parallel to monitor changes in the SRP concentration over the incubation period. At $t=0,12$ and $24 \mathrm{~h} 100 \mathrm{ml}$ portions were collected from the non-radiolabeled series for SRP and TDP measurements. All samples were immediately frozen and stored at $-20^{\circ} \mathrm{C}$ for subsequent laboratory analyses.

Intracellular ATP pool labeling experiments. To assess the size of the initial BAP pool the specific labeling of the $\gamma$ position of ATP was used (Karl \& Bossard 1985). On 4 occasions experiments were conducted to measure the kinetics of ATP pool labeling following the addition of ${ }^{32} \mathrm{P}_{\mathrm{i}}$. Samples were collected 9 times over a $12 \mathrm{~h}$ incubation period, with more frequent sampling in the beginning, when the rate of change of the specific activity of the particulate ATP pool is expected to be the greatest. At each sampling time the content of an entire incubation bottle $(450 \mathrm{ml})$ was filtered through a GF/F filter and extracted in boiling Tris buffer (see above). The extract was stored frozen until further processed following procedures described elsewhere (Karl \& Bossard 1985, Bossard \& Karl 1986, Karl et al. 1987, Karl 1993). Briefly, the Tris extract was concentrated by vacuum evaporation and the ATP purified using polyethyleneimine (PEI) thin-layer chromatography. The isolated ${ }^{32} \mathrm{P}$-ATP was eluted from the PEI matrix and hydrolyzed with apyrase (Sigma Chemical Co., \#A6132) to estimate the respective radioactivities of the $\alpha, \beta$, and $\gamma$ positions of ATP as a function of time. The data were fitted using a non-linear function formula, similar to PROCNLIN (Karl et al. 1987), to estimate the maximum specific radioactivitity of the $\gamma$ P. This value was used to estimate the size of the BAP pool. 
Laboratory analysis and calculations. Radioactivity was determined using a Packard Tri-Carb ${ }^{\circledR}$ scintillation counter. Aquasol II was used as the fluor, and the samples were quench corrected using Packard Instruments SIS protocols. Uptake rates of ${ }^{32} \mathrm{P}_{i}$ were determined from the slope of the ${ }^{32} \mathrm{P}$-particulate activities versus incubation time, calculated from the least square regression analysis over a time period where the uptake was linear, generally the first 8 to $12 \mathrm{~h}$ of incubation. Turnover time ( $T$, in days) was calculated as:

$$
T=a / r
$$

where $a$ is the total ${ }^{32} \mathrm{P}_{\mathrm{i}}$ activity (Bq $\mathrm{l}^{-1}$ ) added to the samples and $r$ is the uptake rate into the particulate fraction $\left(\mathrm{Bq} \mathrm{l}^{-1} \mathrm{~d}^{-1}\right)$. The rate of phosphate uptake, expressed as nM SRP $d^{-1}$, was calculated from $T$ and the measured concentration of the SRP. Note, however, that these uptake rates must be regarded as approximations as they are based on analytically derived values for phosphate pool concentrations and the rate estimate will depend on the choice of analysis. Theoretically, the potential BAP pool concentrations can range from free $P_{i}$ to TDP.

In the experiments where known organic $\mathrm{P}$ compounds were tested, the net regeneration of $P_{i}$ over an approximately $24 \mathrm{~h}$ incubation period, expressed as $\mathrm{nM} \mathrm{P} \mathrm{d}{ }^{-1}$, was termed the phosphorus regeneration potential (PRP). The PRP was calculated as the change in SRP concentration in the organic P amended samples over time and corrected for any changes in the control samples:

$$
\mathrm{PRP}=\left(\left[\mathrm{SRP}_{\mathrm{E}}\right]-\left[\mathrm{SRP}_{\mathrm{C}}\right]\right) / t
$$

where $\mathrm{SRP}_{\mathrm{E}}$ and $\mathrm{SRP}_{\mathrm{C}}$ are the net changes in SRP (nM) during the incubation period in the experimental and control samples respectively, and $t$ is the incubation time in days.

The relative bioavailability of the different organic $\mathrm{P}$ compounds tested, the bioavailability factor (BF), was estimated as previously described (Björkman \& Karl 1994). $\mathrm{BF}$ is the isotope dilution effect in ${ }^{32} \mathrm{P}_{\mathrm{i}}$ uptake caused by a particular organic $\mathrm{P}$ compound, relative to the $\mathrm{P}$ turnover time in control incubations:

$$
\mathrm{BF}=\left(T_{\mathrm{E}}-T_{\mathrm{N}}\right) /\left(T_{\mathrm{P}}-T_{\mathrm{N}}\right)
$$

where $T_{\mathrm{E}}$ is the $\mathrm{P}_{\mathrm{i}}$ pool turnover time in the experimental treatment, $T_{\mathrm{N}}$ is the $\mathrm{P}_{\mathrm{i}}$ pool turnover time in the negative control (no $\mathrm{P}$ addition), and $T_{\mathrm{P}}$ is the $\mathrm{P}_{\mathrm{i}}$ pool turnover time in the positive control ( $\mathrm{P}_{\mathrm{i}}$ addition). In theory $\mathrm{BF}$ values can range from 0 to 1 , where 0 represents a biorefractory substrate and 1 is a $\mathrm{P}$ compound with a bioavailability equal to that of $\mathrm{P}_{\mathrm{i}}$.

Production rates of DOP were measured using the modified MAGIC method (Thomson-Bulldis \& Karl
1998). Analyses were performed using the filtrates collected from the light and dark $\mathrm{P}_{\mathrm{i}}$ uptake experiments. A portion of each sample was placed into a $50 \mathrm{ml}$ centrifuge tube and a $1 \mathrm{ml}$ subsample was removed, for the measurement of the total ${ }^{32} \mathrm{P}$ activity, prior to an addition of a $0.5 \% \mathrm{vol} / \mathrm{vol}$ ratio of $\mathrm{NaOH}(1 \mathrm{M})$. The samples were mixed, then centrifuged for $1 \mathrm{~h}$ at $1000 \times g$ to separate ${ }^{32} \mathrm{P}_{\mathrm{i}}$, which is co-precipitated with brucite $\left(\mathrm{Mg}(\mathrm{OH})_{2}\right)$, from the organic P compounds that largely remain in solution (Thomson-Bulldis \& Karl 1998). A portion of the supernatant was analyzed for ${ }^{32} \mathrm{P}$ activity by LSC. The rate of $\mathrm{DO}^{32} \mathrm{P}$ production was determined from the increase in ${ }^{32} \mathrm{P}$ activity over time during the time period where the production was linear (usually 0.5 to $1 \mathrm{~d}$ ). The calculation of DOP production rates, as $\mathrm{nM} \mathrm{d}^{-1}$, was made by assuming that newly formed DOP will have a specific activity equivalent to the initial specific activity of the $\mathrm{P}_{\mathrm{i}}$ pool (i.e., $\mathrm{Bq}^{32} \mathrm{P} \mathrm{mol}^{-1}\left[{ }^{32} \mathrm{P}_{\mathrm{i}}\right.$ $\left.\left.+{ }^{31} \mathrm{P}_{\mathrm{i}}\right]=\mathrm{Bq} \mathrm{DO}{ }^{32} \mathrm{P} \mathrm{mol}^{-1}\left[\mathrm{DO}^{32} \mathrm{P}+\mathrm{DO}^{31} \mathrm{P}_{\text {new }}\right]\right) . T$ of the ambient DOP pool was then calculated as:

$$
T=[\mathrm{DOP}] / \mathrm{PR}_{\mathrm{DOP}}
$$

where $\mathrm{PR}_{\mathrm{DOP}}$ is the production rate of DOP in $\mathrm{nM} \mathrm{d}^{-1}$ and [DOP] is the concentration of the DOP in the supernatant of the analyzed sample.

\section{RESULTS}

\section{Dissolved and particulate material and microbial community composition}

Ambient inorganic nutrient concentrations were low at all stations, typical for the oligotrophic NPSG (Table 1). SRP concentrations averaged $<50 \mathrm{nM}$, with a minimum of $14 \pm 1 \mathrm{nM}$ at Stn Climax in July 1997. $\mathrm{P}_{\mathrm{i}}$ averaged $63 \pm 10 \%$ (range 42 to $93 \%$ ) of the corresponding SRP concentrations. For all station locations and dates, DOP exceeded $\mathrm{P}_{\mathrm{i}}$, sometimes by 1 order of magnitude (Table 1).

For all station locations and dates, DON exceeded $\left[\mathrm{NO}_{3}{ }^{-}+\mathrm{NO}_{2}^{-}\right]$concentrations by 3 to 4 orders of magnitude (Table 1). The TDN:TDP ratios were consistently enriched in $\mathrm{N}$ relative to $\mathrm{P}$ and ranged from $17: 1$ to 39:1 (median 22:1, mean 23.6:1, $\mathrm{n}=7$ ), as were the ratios of DON:DOP, compared to the classical Redfield molar ratio of 16N:1P (Redfield et al. 1963).

The mean particulate matter concentration in surface waters at Stns ALOHA and Climax was $2.31 \pm 0.24 \mu \mathrm{M}$ PC $(\mathrm{n}=6), 0.30 \pm 0.08 \mu \mathrm{M}$ PN $(\mathrm{n}=7)$, and $14.8 \pm 1.8 \mathrm{nM}$ PP $(\mathrm{n}=7$; Table 2$)$. The N:P ratios in the particulate matter during summer ranged from 18:1 to 24:1 (mean $20: 1$, median $22: 1, \mathrm{n}=6$ ). The estimated total living biomass by particulate ATP ranged from 6.7 to $15.4 \mu \mathrm{g}$ $\mathrm{Cl}^{-1}$ (mean $9.1 \pm 2.9 \mu \mathrm{g} \mathrm{Cl}^{-1}$, median $8.0 \mu \mathrm{C} \mathrm{Cl}^{-1}, \mathrm{n}=7$ ). 
Table 1. Dissolved phosphorus and nitrogen concentrations and concentration ratios for water samples collected at $5 \mathrm{~m}$ depth in the North Pacific subtropical gyre (NPSG) at Stn ALOHA $\left(22.75^{\circ} \mathrm{N}, 158.00^{\circ} \mathrm{W}\right)$ and $\operatorname{Stn}$ Climax $\left(28.11^{\circ} \mathrm{N}, 155.36^{\circ} \mathrm{W}\right)$. SRP $=\mathrm{solu}-$ ble reactive phosphorus, $\mathrm{P}_{\mathrm{i}}=$ inorganic phosphate, $\mathrm{DOP}=$ dissolved organic phosphorus (TDP-SRP), TDP = total dissolved phosphorus, $\mathrm{BAP}=$ biologically available phosphorus, $\mathrm{N}+\mathrm{N}=\left[\mathrm{NO}_{3}{ }^{-}+\mathrm{NO}_{2}{ }^{-}\right], \mathrm{TDN}=$ total dissolved nitrogen. $-=$ not determined, $\mathrm{BDL}=$ below detection limit

\begin{tabular}{|c|c|c|c|c|c|c|c|c|c|c|}
\hline Stn & Cruise date & $\begin{array}{l}\text { SRP } \\
(\mathrm{nM})\end{array}$ & $\begin{array}{c}\mathrm{P}_{\mathrm{i}} \\
(\mathrm{nM})\end{array}$ & $\begin{array}{l}\text { DOP } \\
(\mathrm{nM})\end{array}$ & $\begin{array}{l}\text { TDP } \\
(\mathrm{nM})\end{array}$ & $\begin{array}{l}\text { BAP } \\
\text { (nM) }\end{array}$ & $\begin{array}{l}\mathrm{N}+\mathrm{N} \\
(\mathrm{nM})\end{array}$ & $\begin{array}{l}\text { TDN } \\
(\mathrm{nM})\end{array}$ & $\begin{array}{c}\text { DON:DOP } \\
\text { (mol:mol) }\end{array}$ & $\begin{array}{l}\text { TDN:TDP } \\
\text { (mol:mol) }\end{array}$ \\
\hline ALOHA & Jul 1996 & $119 \pm 2$ & $76 \pm 2$ & $231 \pm 2$ & 350 & - & 1.0 & 5870 & $25: 1$ & $17: 1$ \\
\hline Climax & Jul 1996 & $45 \pm 3$ & $19 \pm 3$ & $140 \pm 3$ & 185 & - & BDL & 4600 & $33: 1$ & $24: 1$ \\
\hline $\begin{array}{l}\text { ALOHA } \\
\text { (HOT 78) }\end{array}$ & Dec 1996 & $25 \pm 0$ & - & $245 \pm 0$ & 270 & - & 0.5 & 5250 & $21: 1$ & $19: 1$ \\
\hline $\begin{array}{l}\text { ALOHA } \\
\text { (HOT 84) }\end{array}$ & Jun 1997 & $55 \pm 2$ & - & $285 \pm 2$ & 340 & $111 \pm 16$ & 0.3 & 5730 & $20: 1$ & $17: 1$ \\
\hline ALOHA & Jul 1997 & $43 \pm 1$ & $31 \pm 3$ & $195 \pm 1$ & 238 & $56 \pm 6$ & 0.4 & 5210 & $27: 1$ & $22: 1$ \\
\hline Climax & Jul 1997 & $14 \pm 1$ & $13 \pm 2$ & $141 \pm 1$ & 155 & $13 \pm 1$ & 0.8 & 6120 & $43: 1$ & $39: 1$ \\
\hline $\begin{array}{l}\text { ALOHA } \\
\text { (HOT 86) }\end{array}$ & Aug 1997 & $22 \pm 1$ & - & $238 \pm 1$ & 260 & $50 \pm 3$ & 0.2 & 6940 & $29: 1$ & $27: 1$ \\
\hline
\end{tabular}

Flow cytometry data revealed a remarkably similar composition of the microbial community between stations and years (Table 3). The microbial community was dominated by prokaryotic organisms. Prochlorococcus spp. dominated the phototrophic component (>97\% by numbers) and constituted between 20 and $30 \%$ of the total prokaryotes. In biomass terms Prochlorococcus spp. contributed $6.6 \pm 1.2 \mu \mathrm{g} \mathrm{Cl}^{-1}$ (range 5.1 to $8.6 \mu \mathrm{g} \mathrm{C}^{-1}, \mathrm{n}=7$ ), or $50.1 \pm 10.7 \%$ of the total microbial biomass (Table 3 ).

Table 2. Living and total particulate matter pools for water samples collected in the NPSG. chl $a=$ chlorophyll $a$, ATP = adenosine-5' -triphosphate, PC = particulate carbon, $\mathrm{PN}=$ particulate nitrogen, $\mathrm{PP}=$ particulate phosphorus. Values are mean \pm 1 standard deviation (where shown). For PC, PN and PP samples $\mathrm{n}=1 .-=$ not determined

\begin{tabular}{|llcccccc|}
\hline Stn & Cruise date & $\begin{array}{c}\text { Chl a } \\
\left(\mathrm{ng} \mathrm{l}^{-1}\right)\end{array}$ & $\begin{array}{c}\text { ATP } \\
\left(\mathrm{ng} \mathrm{l}^{-1}\right)\end{array}$ & $\begin{array}{c}\mathrm{PC} \\
(\mu \mathrm{M})\end{array}$ & $\begin{array}{c}\mathrm{PN} \\
(\mu \mathrm{M})\end{array}$ & $\begin{array}{c}\text { PP } \\
(\mu \mathrm{M})\end{array}$ & $\begin{array}{c}\text { PC:PN:PP } \\
(\mathrm{mol})\end{array}$ \\
\hline ALOHA & Jul 1996 & $40 \pm 1$ & 26.8 & - & 0.22 & 0.013 & $-: 18: 1$ \\
Climax & Jul 1996 & $55 \pm 6$ & 34.7 & 2.53 & 0.36 & 0.015 & $163: 23: 1$ \\
ALOHA & $\begin{array}{l}\text { Dec 1996 } \\
\text { (HOT 78) }\end{array}$ & $150 \pm 0$ & 31.9 & 2.13 & 0.16 & 0.013 & $170: 12: 1$ \\
ALOHA & Jun 1997 & $58 \pm 1$ & 30.3 & 2.16 & 0.29 & 0.013 & $163: 22: 1$ \\
& (HOT 84) & & & & & & \\
ALOHA & Jul 1997 & $72 \pm 2$ & 32.8 & 2.00 & 0.36 & 0.017 & $119: 22: 1$ \\
Climax & Jul 1997 & $71 \pm 2$ & 36.6 & 2.57 & 0.33 & 0.017 & $156: 20: 1$ \\
ALOHA & $\begin{array}{l}\text { Aug 1997 } \\
\text { (HOT 86) }\end{array}$ & $54 \pm 3$ & 61.4 & 2.47 & 0.37 & 0.016 & $156: 24: 1$ \\
& & & & & & \\
\hline
\end{tabular}

\section{Phosphate uptake rates and turnover times}

Net phosphate uptake rates in the light at ambient $P$ concentrations varied between 3.0 and $8.2 \mathrm{nM} \mathrm{d}^{-1}$ (median $=3.5 \mathrm{nM} \mathrm{d}^{-1}, \mathrm{n}=7$; Table 4$)$. The turnover times of the $P_{i}$ pool varied from 2 to $40 \mathrm{~d}$ (median $=9 \mathrm{~d}$, $\mathrm{n}=7$ ). Uptake and regeneration rates appeared to be balanced, because the concentration of SRP remained constant over the course of incubation. However, in samples with exogenous $\mathrm{P}_{\mathrm{i}}$ additions $\geq 2$-fold the ambient concentrations, an uncoupling between $\mathrm{P}_{\mathrm{i}}$ uptake and $\mathrm{P}_{\mathrm{i}}$ regeneration was observed. This resulted in a net decrease in SRP concentration with time at Stn ALOHA (Table 5). Uptake rates in these latter experiments increased with higher $P_{i}$ loading and reached the highest net uptake rate $\left(6.3 \pm 0.3 \mathrm{nM} \mathrm{d}^{-1}\right)$ at a $\mathrm{P}_{\mathrm{i}}$ concentration of $170 \mathrm{nM}$ at Stn ALOHA. At Stn Climax, however, the $\mathrm{P}_{\mathrm{i}}$ uptake rates continued to increase linearly even up to the highest $\mathrm{P}_{\mathrm{i}}$ concentration tested (Table 5).

\section{Light versus dark phosphate uptake}

The uptake rates from day-night incubation experiments were compared to bottles kept in continuous darkness for $24 \mathrm{~h}$. In 3 out of 5 experiments the particulate uptake rates in the dark were re- 
Table 3. Microbial population estimates and community composition for water samples collected in the NPSG. HB = heterotrophic bacteria (i.e., non-pigmented Bacteria and Archaea), PRO = Prochlorococcus spp., SYN = Synechococcus spp., PEUK = pico-eukaryotic cells, TM = total microbial cells by flow cytometry, ATP = adenosine-5'-triphosphate. Biomass $\left(\mu \mathrm{g} C \mathrm{l}^{-1}\right) \mathrm{were}$ based on the following conversion factors $(\mathrm{g} / \mathrm{g})$ : C/ATP $=250$ (Karl 1980). For cell numbers (fg cell $\left.{ }^{-1}\right)$ : HB = 10 (Christian \& Karl 1994), $\mathrm{PRO}=30, \mathrm{SYN}=100, \mathrm{PEUK}=495$ (Chavez et al. 1996, Zubkov et al. 1998)

\begin{tabular}{|c|c|c|c|c|c|c|c|c|c|c|c|c|}
\hline \multirow[t]{2}{*}{ Stn } & \multirow[t]{2}{*}{ Cruise date } & \multicolumn{5}{|c|}{ Cell numbers $\left(10^{6} 1^{-1}\right)$} & \multicolumn{6}{|c|}{ Biomass $\left(\mu g \mathrm{C}^{-1}\right)$} \\
\hline & & HB & PRO & SYN & PEUK & $\mathrm{TM}$ & ATP & HB & PRO & SYN & PEUK & TM \\
\hline ALOHA & Jul 1996 & 596 & 230 & 1.76 & 0.05 & 828 & 6.7 & 5.96 & 6.90 & 0.18 & 0.02 & 13.06 \\
\hline Climax & Jul 1996 & 616 & 242 & 2.78 & 0.10 & 861 & 8.7 & 6.16 & 7.27 & 0.28 & 0.05 & 13.76 \\
\hline ALOHA & $\begin{array}{l}\text { Dec } 1996 \\
\text { (HOT 78) }\end{array}$ & 450 & 235 & 1.27 & 1.05 & 687 & 8.0 & 4.50 & 7.05 & 0.13 & 0.51 & 12.19 \\
\hline ALOHA & $\begin{array}{l}\text { Jun } 1997 \\
\text { (HOT 84) }\end{array}$ & 530 & 194 & 1.26 & 0.39 & 726 & 7.6 & 5.30 & 5.82 & 0.13 & 0.19 & 11.44 \\
\hline ALOHA & Jul 1997 & 701 & 184 & 2.05 & 1.00 & 889 & 8.2 & 7.01 & 5.53 & 0.20 & 0.50 & 13.24 \\
\hline Climax & Jul 1997 & 663 & 169 & 3.62 & 0.90 & 836 & 9.1 & 6.63 & 5.07 & 0.36 & 0.45 & 12.51 \\
\hline ALOHA & $\begin{array}{l}\text { Aug } 1997 \\
\text { (HOT 86) }\end{array}$ & 684 & 287 & 1.92 & 1.01 & 974 & 15.4 & 6.84 & 8.61 & 0.19 & 0.50 & 16.14 \\
\hline
\end{tabular}

duced by 40 to $50 \%$ compared to rates in light incubations. However, on 2 separate occasions at Stn ALOHA (December 1996, July 1997), the light and dark phosphate uptake rates were nearly identical (Fig. 2, Table 4).

\section{DOP production rates and DOP pool turnover}

Net DOP production rates ranged from 0.6 to $2.5 \mathrm{nM}$ $\mathrm{P} \mathrm{d}^{-1}$, equivalent to approximately 10 and $40 \%$, respectively, of the net $\mathrm{P}_{\mathrm{i}}$ uptake rate (Table 4 ). At a given station this ratio was constant regardless of whether the incubations were day-night or dark treatments, with the exception of the December 1996 experiment (HOT 78), for which we also observed a significant light versus dark difference in $\mathrm{P}_{\mathrm{i}}$ uptake rates. The turnover times of the total DOP pool ranged from 40 to $300 \mathrm{~d}$.

\section{Bioavailable phosphorus pool}

Several estimates of the BAP pool were made using different techniques. Results from experiments using additions of known concentrations of $P_{i}$ to seawater samples, to ascertain if the bioavailable fraction differed from the ambient $\mathrm{P}_{\mathrm{i}}$ pools, were inconclusive. These experiments indicated either that the measured $\mathrm{P}_{\mathrm{i}}$ concentrations were equal to the BAP pool or that the exogenous $\mathrm{P}_{\mathrm{i}}$ caused an increase in community uptake rates (Table 5), thereby violating the primary assumption of this experimental design. When using the specific radioactivity of the intracellular ATP pool as a means of assessing the total BAP pool, results indicated that the BAP pool could range from being equal to, or up to twice that of, the measured $\mathrm{P}_{\mathrm{i}}$ pool (Table 1).

Table 4. Phosphate uptake rates, production of DOP, and primary production measured by ${ }^{14} \mathrm{C}$-bicarbonate incorporation for water samples collected in the NPSG. SRP uptake $=$ soluble reactive phosphorus uptake based on the SRP or $\mathrm{P}_{i}$ concentrations, $\mathrm{P}=$ phosphorus, $1^{\circ}$ production $=$ primary production. $\mathrm{C}: \mathrm{P}$ uptake ratios were calculated by converting $1^{\circ}$ production from $\mu \mathrm{g} \mathrm{l}^{-1} \mathrm{~h}^{-1}$ to $\mathrm{nM} \mathrm{h}^{-1}$ and dividing by the light-dependent $\mathrm{P}$ uptake rate $\left(\mathrm{nM} \mathrm{h}^{-1}\right) .-=$ not determined

\begin{tabular}{|c|c|c|c|c|c|c|c|c|c|}
\hline \multirow[t]{2}{*}{ Stn } & \multirow[t]{2}{*}{ Cruise date } & \multicolumn{2}{|c|}{$\begin{array}{l}\text { SRP uptake } \\
\left(\mathrm{nM} \mathrm{d}^{-1}\right)\end{array}$} & \multicolumn{2}{|c|}{$\begin{array}{l}\text { P turnover time } \\
\text { (d) }\end{array}$} & \multirow[t]{2}{*}{$\begin{array}{l}1^{\circ} \text { production } \\
\left(\mu \mathrm{C} \mathrm{C}^{-1} \mathrm{~h}^{-1}\right)\end{array}$} & \multicolumn{2}{|c|}{$\begin{array}{l}\text { DOP production } \\
\quad\left(\mathrm{nM} \mathrm{P} \mathrm{d}^{-1}\right)\end{array}$} & \multirow[t]{2}{*}{$\begin{array}{l}\text { C:P uptake } \\
\text { (mol:mol) }\end{array}$} \\
\hline & & Light & Dark & Light & Dark & & Light & Dark & \\
\hline ALOHA & Jul 1996 & $3.02 \pm 0.25$ & $1.40 \pm 0.02$ & 40 & 85 & 0.57 & - & - & $377: 1$ \\
\hline Climax & Jul 1996 & $3.05 \pm 0.67$ & $1.92 \pm 0.12$ & 9 & 15 & 0.49 & - & - & $321: 1$ \\
\hline ALOHA & $\begin{array}{l}\text { Dec } 1996 \\
(\text { HOT } 78)\end{array}$ & $8.17 \pm 0.73$ & $10.67 \pm 1.93$ & 3 & 2.4 & $0.39 \pm 0.09$ & $2.32 \pm 0.21$ & $0.97 \pm 1.34$ & $95: 1$ \\
\hline ALOHA & $\begin{array}{l}\text { Jun } 1997 \\
\text { (HOT 84) }\end{array}$ & $3.80 \pm 0.89$ & - & 14 & - & $0.63 \pm 0.17$ & - & - & $333: 1$ \\
\hline ALOHA & Jul 1997 & $3.47 \pm 0.18$ & $3.73 \pm 0.24$ & 9 & 8 & - & $0.72 \pm 0.12$ & $0.62 \pm 0.07$ & - \\
\hline Climax & Jul 1997 & $6.59 \pm 0.60$ & $3.14 \pm 0.31$ & 2 & 4 & $0.26 \pm 0.01$ & $2.46 \pm 0.53$ & $1.22 \pm 0.17$ & $74: 1$ \\
\hline ALOHA & $\begin{array}{l}\text { Aug } 1997 \\
\text { (HOT 86) }\end{array}$ & $3.36 \pm 0.12$ & - & 6 & - & $0.25 \pm 0.00$ & - & - & $146: 1$ \\
\hline
\end{tabular}



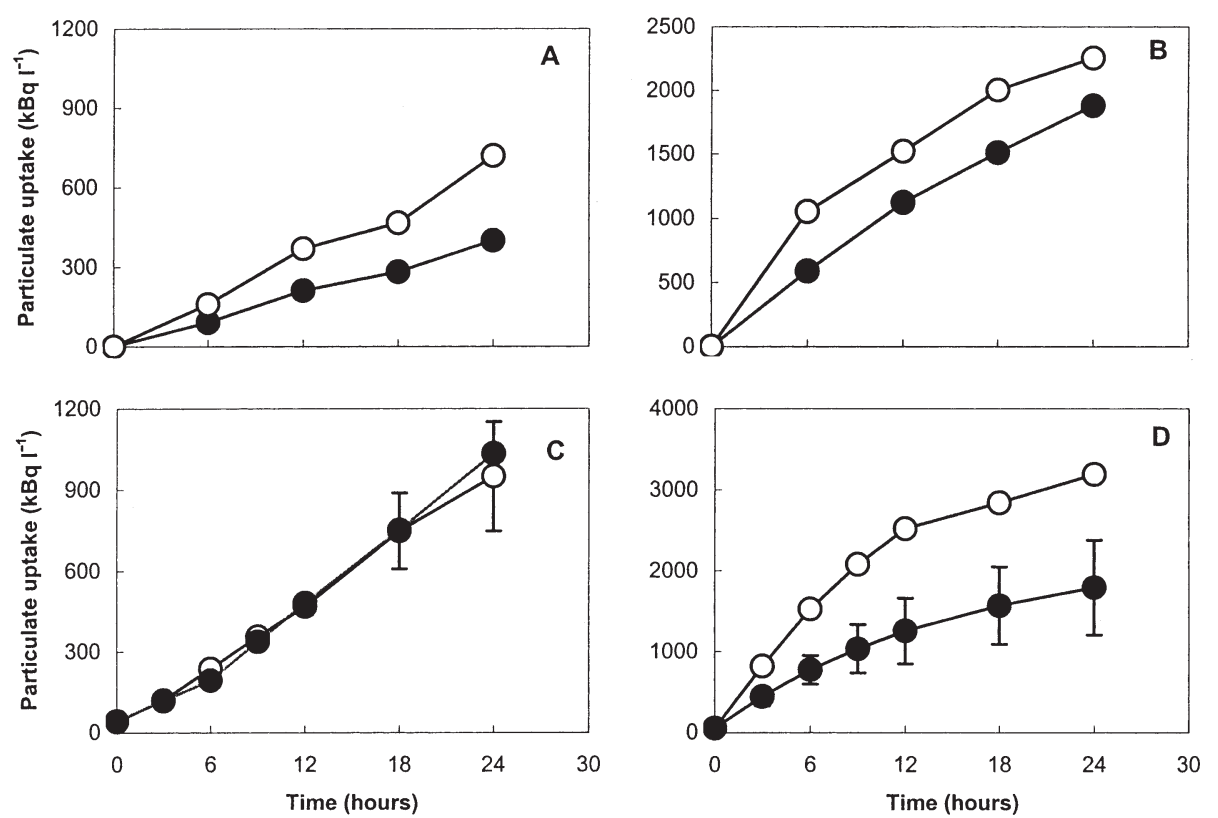

Fig. 2. Representative timecourse experiment showing the uptake of ${ }^{32} \mathrm{P}_{\mathrm{i}}$ by natural assemblages of microorganisms collected in the NPSG. Incubations were either in continuous darkness (-) or under natural light (O). (A) ALOHA July 1996, (B) Climax July 1996, (C) ALOHA July 1997, (D) Climax July 1997. Error bars are \pm 1 standard deviation from the mean of duplicate samples. Error bars are sometimes smaller than the symbols used

\section{Bioavailability of selected DOP compounds}

When specific combined P compounds were added to seawater samples, nucleotides and RuBP appeared to be more bioavailable than monophosphate esters. However, $\mathrm{P}_{\mathrm{i}}$ was always the most readily available, and presumably the 'preferred' substrate for the growth of marine microorganisms in the NPSG. The PRP varied among the tested compounds and among cruises, ranging from $0 \mathrm{nM} \mathrm{d}^{-1}$ for PEP to over $200 \mathrm{nM} \mathrm{d}^{-1}$ for ATP. The proportion of the exogenous DOP converted to SRP over a $24 \mathrm{~h}$ period could be $>65 \%$ for selected compounds; the highest values were observed for nucleotides. The PRP was generally higher than the calculated net uptake rates of SRP which ranged from 2.9 to $9.6 \mathrm{nM} \mathrm{d}^{-1}$ in the control incubations, and the $\mathrm{P}$ release rates from exogenous nucleotides could exceed the rate of P uptake by as much as 50-fold (Fig. 3, Table 4).

\section{DISCUSSION}

At the time of the establishment of the HOT program and its deep water hydrographic Stn ALOHA in October 1988, the NPSG was largely considered a relatively homogenous and static environment (Karl \& Lukas 1996). However, over the past decade a new view has emerged, indicating that this ecosystem is more dynamic than previously assumed (Karl 1999). Historical data on nutrient dynamics in the oligotrophic NPSG, to a large extent, stem from studies conducted within the Climax region, which was intermittently sampled between 1968 and 1985 (Hayward 1987). Observations made in the Climax region over this nearly 2-decadelong investigation period revealed several significant changes in fundamental biological parameters. Venrick et al. (1987), for example, observed a nearly 2-fold increase in chl a concentration (integrated 0 to $200 \mathrm{~m}$, $12.7 \pm 3.4 \mathrm{mg} \mathrm{m}^{-2}$ prior to $1973,22.0 \pm 2.2 \mathrm{mg} \mathrm{m}^{-2}$ following 1980) over the $17 \mathrm{yr}$ period. At Stn ALOHA the chl a concentrations have remained at a level consistent with the higher chl a reported by Venrick et al. (1987) at $22.5 \pm 4.6 \mathrm{mg} \mathrm{m}^{-2}$ (integrated 0 to $200 \mathrm{~m}$ ) since the beginning of the HOT program in 1988 (Karl et al.

Table 5. Effects of $P_{\mathrm{i}}$ addition on rates of phosphate uptake for samples collected in the NSPG. $\Delta \mathrm{P}_{\mathrm{i}}=$ difference between initial and endpoint $\mathrm{P}_{\mathrm{i}}$ concentration, $\mathrm{P}_{\mathrm{i}}$ turnover $=$ phosphate pool turnover time. Data are mean \pm 1 standard deviation (where shown)

\begin{tabular}{|lcccc|}
\hline $\begin{array}{l}\text { Sample and } \\
\text { treatment }\end{array}$ & $\begin{array}{c}\mathrm{P}_{\mathrm{i}} \\
(\mathrm{nM})\end{array}$ & $\begin{array}{c}\Delta \mathrm{P}_{\mathrm{i}} \\
(\mathrm{nM})\end{array}$ & $\begin{array}{c}\mathrm{P}_{\mathrm{i}} \text { uptake } \\
\left(\mathrm{nM} \mathrm{d}^{-1}\right)\end{array}$ & $\begin{array}{c}\mathrm{P}_{\mathrm{i}} \text { turnover } \\
(\mathrm{d})\end{array}$ \\
\hline Stn ALOHA & & & & \\
Control & $31 \pm 2$ & - & $3.3 \pm 0.1$ & 10.3 \\
1 & $54(\mathrm{n}=1)$ & $1 \pm 2$ & $3.3 \pm 0.1$ & 16.2 \\
2 & $99(\mathrm{n}=1)$ & $-30 \pm 11$ & $5.1 \pm 1.2$ & 19.6 \\
3 & $171 \pm 2$ & $-42 \pm 11$ & $6.3 \pm 0.3$ & 26.9 \\
4 & $326 \pm 4$ & $-88 \pm 4$ & $5.9 \pm 0.6$ & 55.6 \\
Stn Climax & & & & \\
Control & $13 \pm 1$ & - & $6.6 \pm 0.6$ & 2.0 \\
1 & $36 \pm 2$ & $-4 \pm 2$ & $6.2 \pm 0.9$ & 5.8 \\
2 & $49 \pm 0$ & $0 \pm 2$ & $5.8 \pm 0.6$ & 8.5 \\
3 & $72 \pm 8$ & $2 \pm 8$ & $6.5 \pm 0.9$ & 11.1 \\
4 & $138 \pm 4$ & $7 \pm 4$ & $7.5 \pm 1.4$ & 18.4 \\
5 & $249 \pm 0$ & $24 \pm 1$ & $9.2 \pm 1.5$ & 27.0 \\
& & & & \\
\hline
\end{tabular}


2000a). Furthermore, recent evidence suggests that the ecosystem has undergone dramatic changes in the past decade on several levels, including a change from a predominantly $\mathrm{N}$-controlled to a potentially P-controlled environment, with profound effects on food web structure and nutrient cycling pathways (Karl 1999). These ecosystem changes are hypothesized to be governed by predominantly climatological factors, such as an intensification of the occurrence and duration of El Niño Southern Oscillation (ENSO) events, which have given rise to changing circulation and mixing patterns, and the Pacific Decadal Oscillation
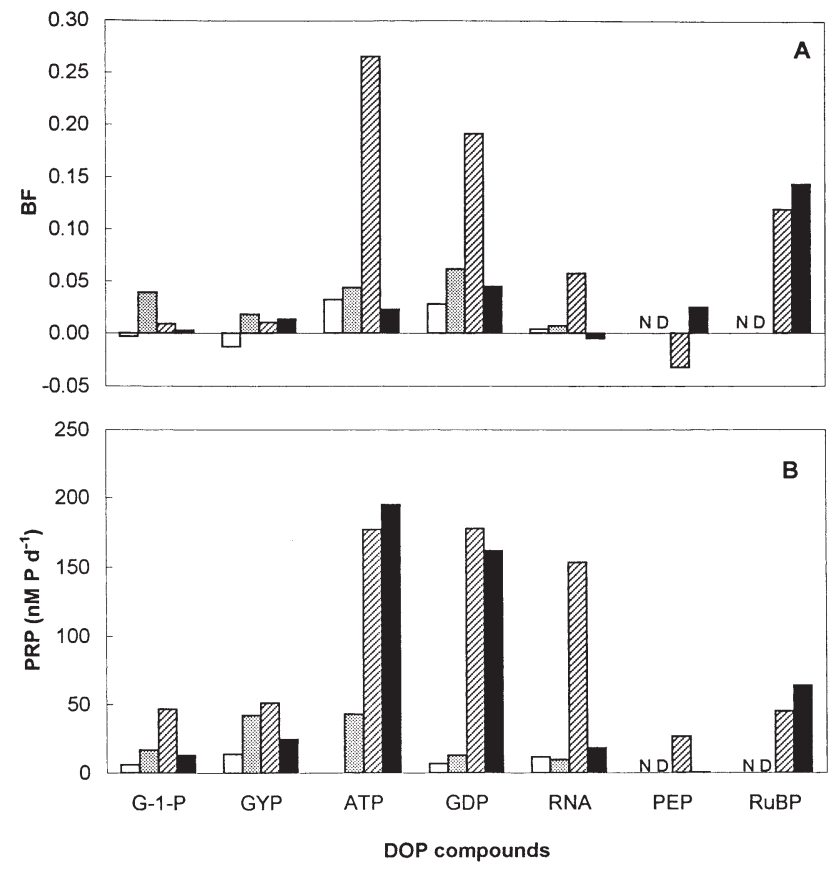

Fig. 3. Bioavailability of selected DOP compounds to natural assemblages of microorganisms in seawater samples collected in the NPSG. All exogenous compounds were added at 250 nM P. G-1-P = glucose-1-phosphate, GYP = glycerophosphate, ATP = adenosine- 5 '-triphosphate, GDP = guanosine5 -diphosphate, RNA $=$ ribonucleic acid, $\mathrm{PEP}=$ phosphoenol pyruvate, RuBP = ribulose-1,5-bisphosphate. (A) Bioavailability factor $(\mathrm{BF})$. This is an experimentally derived estimate of the utilization of each compound tested, measured by the isotope dilution of ${ }^{32} \mathrm{P}_{\mathrm{i}}$ relative to a positive control sample with an equivalent inorganic phosphorus $\left(\mathrm{P}_{\mathrm{i}}\right)$ addition, the presumed preferred substrate, and a negative control with no exogenous substrate. Scaled bioavailability ranges from 0 to 1 , with a score of 0 indicating an unavailable substrate and 1 indicative of a substrate with an availability equivalent to that of $P_{i}$. See text for further details. Negative BF values result from a slight enhancement in uptake rates in incubations with exogenous DOP relative to the negative controls. (B) Phosphorus regeneration potential (PRP). This is the experimentally derived estimate of $\mathrm{P}_{\mathrm{i}}$ release from each $250 \mathrm{nM}$ substrate addition following a timed incubation of $24 \mathrm{~h}$. Bars are: ALOHA July 1996 = unfilled, Climax July 1996 = stippled, ALOHA July 1997 = hatched, Climax July 1997 = solid, ND = no data
(PDO). These conditions are believed to have selected for $\mathrm{N}_{2}$-fixing organisms, such as Trichodesmium spp., and their activities have resulted in a replenishment of the fixed $\mathrm{N}$ inventory in the upper ocean driving the NPSG ecosystem towards P limitation (Karl et al. 1995, 1997, Cullen et al. 2000).

P limitation has recently been demonstrated in other marine environments such as in the Sargasso Sea (Cotner et al. 1997, Wu et al. 2000) and the eastern Mediterranean Sea (Krom et al. 1991, Zohary \& Robarts 1998). Both of these ecosystems exhibit extremely low $P_{i}$ concentrations $(<10 \mathrm{nM})$ and TDN:TDP ratios of $>20: 1$, similar to present ratios observed in the NPSG. One proposed reason for the current P limited state of the North Atlantic region is an increased deposition of iron $(\mathrm{Fe})$-rich eolian dust. This may have relieved Fe deficiency in diazotrophic organisms and consequently allowed for increased $\mathrm{N}_{2}$ fixation (Cotner et al. 1997). Alternatively, Fe-rich clay particles may provide a matrix onto which $\mathrm{P}$ is selectively adsorbed and subsequently removed from the productive layer as suggested by Krom et al. (1991) for the eastern Mediterranean.

The $\mathrm{P}$ uptake rate calculations presented herein are based on the specific radioactivity of a substrate (i.e., radioactivity per unit concentration). To accurately make these extrapolations, it is necessary to know the pool size into which the radiotracer dilutes. The P pools described here are operationally defined by the method of analyses. The SRP concentrations were determined by the MAGIC method (Karl \& Tien 1992), $P_{i}$ by the modified MAGIC procedure (Thomson-Bulldis \& Karl 1998), and soluble non-reactive phosphorus (assumed to be DOP) by calculating the difference between TDP and SRP (DOP = TDP - SRP). However, SRP, often equated to orthophosphate, will contain both $P_{i}$ and some portion of the base and acid labile DOP pool. The modified MAGIC method will have a smaller, if any, contribution from the DOP pool constituents. Likewise, the DOP pool may well contain non-reactive inorganic combined P compounds. Ultimately, we seek an accurate measure of the BAP pool. In field experiments, added ${ }^{32} \mathrm{P}_{\mathrm{i}}$ will presumably dilute with the ambient ${ }^{31} \mathrm{P}_{\mathrm{i}}$ pool; however, in terms of biological uptake, the tracer will also be diluted by all BAP compounds as well as intracellular pools of $\mathrm{P}$. As such it is necessary, yet presently impossible, to determine the true size of the ecologically relevant P pool. Nevertheless, the size of the BAP pool was estimated by kinetic labeling experiments of the terminal $(\gamma)$ P of particulate ATP during 4 cruises in 1997. Because $\gamma$ ATP has one of the most rapid turnover times of any intracellular $\mathrm{P}$ pool, and ATP is ubiquitous in all living cells, the dynamics of this pool can provide invaluable information on $\mathrm{P}$ sources and fluxes in natural environments (Karl \& 
Bossard 1985). It can be assumed that the specific activity of the $\gamma \mathrm{P}$ of ATP, when the intracellular pool reaches its isotopic equilibrium, will reflect the true specific activity of the external BAP pool. At Stn Climax the BAP pool was equal to the SRP and $\mathrm{P}_{\mathrm{i}}$ pool at $13 \mathrm{nM}$, which is remarkable considering that the DOP pool was $141 \mathrm{nM}$. However, at Stn ALOHA the BAP pool was about 2-fold larger than the $\mathrm{P}_{\mathrm{i}}$ pool, and the SRP pool was intermediate between the $\mathrm{P}$ pool estimates, suggesting that a fraction of the ambient DOP pool was being used simultaneously by the microbial assemblages (Table 1). These differences imply variability in either the microbial population structure, physiological capabilities or chemical composition of the respective DOP pools at the time of sampling, or possibly all three.

Our $\mathrm{P}$ uptake rates, based on SRP or $\mathrm{P}_{\mathrm{i}}$ concentrations, are comparable to values found by Perry \& Eppley (1981) and Sorokin (1985) for samples collected in the NPSG (1.2 and 1.3 to $6.5 \mathrm{nM} \mathrm{P} \mathrm{d}^{-1}$, respectively). Our estimates of the turnover time of the BAP pool are at the lower end of the 19 to $31 \mathrm{~d}$ range reported by Perry \& Eppley (1981) and significantly shorter than the 40 to $100 \mathrm{~d}$ reported by Sorokin (1985). However, data from the hyperoligotrophic Sargasso Sea show $\mathrm{P}_{\mathrm{i}}$ turnover times of approximately $9 \mathrm{~h}$ (Cotner et al. 1997), whereas turnover times in the eastern Mediterranean were highly variable (range: hours to over $35 \mathrm{~d}$ ) even at persistently low concentrations of SRP (Zohary $\&$ Robarts 1998). When uptake rate calculations were made by applying the BAP pool concentrations, the $\mathrm{P}_{\mathrm{i}}$ uptake rates were approximately equal between stations. Also, the difference observed in P concentrations between the two MAGIC procedures used here indicated that a variable portion of the DOP pool was contributing analytically to the determination of SRP concentrations, as previously noted by Thomson-Bulldis \& Karl (1998). Clearly, differences in the BAP pool size relative to the commonly measured concentrations of $\mathrm{SRP}$, or $\mathrm{P}_{\mathrm{i}}$ pool, will have direct consequences in uptake rate estimations as exemplified here. Furthermore, the chemical characteristics of the DOP pool as well as the capacity of the extant community to process DOP is obviously of great importance and will inevitably affect the fate of any given DOP compound. These parameters may well change on temporal and spatial scales and more intensive studies will need to be conducted to elucidate the reason for these differences in BAP pool size and its turnover in different habitats and at different times.

Equally problematic as the need for accurate estimations of the BAP pool is the complete chemical characterization of the P pool constituents, especially the dominant DOP pool. Partial characterization of the DOP pool constituents at Stn ALOHA, based on relative UV photolytic stability, has shown that the DOP pool includes both monophosphate esters and nucleotides, and that the relative chemical composition varies on both temporal and spatial scales (Karl \& Yanagi 1997). However, the origin of this observed variability is unresolved, as is the ecological impact of a chemically dynamic DOP pool. The bioavailability of a certain compound is clearly a time-dependent phenomenon, and is possibly also affected by changing community composition with depth (Simidi \& Tsukamoto 1985), as evident from the decrease in DOP, and parallel increase of $\mathrm{P}_{\mathrm{i}}$ concentrations, with depth. In this present study of phosphorus bioavailability of known DOP compounds, it appeared as if $\mathrm{P}_{\mathrm{i}}$ was the most readily available form of $\mathrm{P}$, a result that is similar to the pattern observed in Hawaiian coastal waters (Björkman \& Karl 1994). Although the $P_{i}$ uptake rates were about 1 order of magnitude lower than those observed in coastal waters (Björkman \& Karl 1994), this may be a result both of lower standing stocks of microorganisms and of concentrations of BAP below the threshold for rapid uptake to take place. The very low PRP and BF at Stn ALOHA in July 1996 (Fig. 3) may be explained by the unusually high SRP concentrations in the surface waters at that time $(\sim 120 \mathrm{nM}$, Table 1$)$. Presumably, these high SRP concentrations were sufficient to satisfy $P$ requirements and may have inhibited/repressed phospho-hydrolytic enzymes, resulting in additional $\mathrm{P}$ sources not being simultaneously utilized. The high PRP rates of nucleotides imply enzymatic activities typically ascribed to 5 '-nucleotidase. This ectoenzyme has been shown to regenerate $\mathrm{P}$ at a rate that frequently exceeds microbial P uptake rates (Siuda \& Güde 1994), and has been hypothesized to provide sufficient $\mathrm{P}$ to fulfill microbial requirements (Tamminen 1989, Ammerman 1991). The high PRP of nucleotides may be an indirect result of microbial scavenging of purine or pyrimidine bases for cellular biosynthesis, rather than providing a primary source for $\mathrm{P}$, hence, net $\mathrm{P}$ regeneration. Such a scavenging mechanism could result in the rapid turnover of at least a portion of the DOP pool, and may be important in P dynamics as a whole. Moreover, the production of DOP was substantial compared to net $\mathrm{P}_{\mathrm{i}}$ uptake rates, indicating that the gross $\mathrm{P}_{\mathrm{i}}$ uptake may be much greater than the net $P_{i}$ uptake reported herein.

DOP is derived from several independent sources. In general DOP is believed to be a product of grazing activities, exudation from healthy cells, leaching from decaying material (Fogg 1966, Sharp 1977, Wood \& van Valen 1990), and virus-induced cell lysis (Proctor \& Fuhrman 1990). The experiments in this study were not designed to elucidate the sources of DOP formation, but rather to estimate the dynamics of this pool. The fraction of particulate $\mathrm{P}$ uptake that resulted in 
DOP production was similar for both light and dark incubations in 2 experiments. This may imply that a constant fraction of the ${ }^{32} \mathrm{P}_{\mathrm{i}}$ incorporated into organisms is regenerated as $\mathrm{DO}^{32} \mathrm{P}$, regardless of whether the $\mathrm{P}$ incorporated was by phototrophic or heterotrophic processes. The estimated turnover time of the DOP pool of 60 to $300 \mathrm{~d}$ is substantially longer than the approximately $10 \mathrm{~d}$ calculated by Orrett \& Karl (1987) for the NPSG, but within the range for DOP turnover of approximately $200 \mathrm{~d}$ calculated from data provided in Jackson \& Williams (1985). (Note that the estimated DOP pool turnover time of $18 \mathrm{~d}$ in the original paper by Jackson \& Williams is due to a conversion error in their calculation.) However, depending on the chemical composition of the DOP pool, significantly faster turnover times may occur for highly bioavailable DOP compounds, and nascent DOP may well be more readily available than older DOP. Consequently, a major uncertainty in these estimates remains due to the inability to characterize the presumably diverse DOP pool. Nevertheless, these estimates of DOP pool turnover times will most likely not be underestimates (see Eq. 4) as the DOP production rate is based on the specific activity of the $\mathrm{P}_{\mathrm{i}}$ pool. If the $\mathrm{P}_{\mathrm{i}}$ pool is less than BAP pool the DOP pool turnover time will be overestimated.

In our experiments, light versus dark incubations showed variable results, ranging from no discernible differences to enhanced P uptake rates in the light relative to dark incubations (Fig. 2). Perry (1976), in her work in the NPSG, and Herbland (1984), in the Equatorial Atlantic Ocean, did not observe diel changes in $\mathrm{P}_{\mathrm{i}}$ uptake rates, nor did light intensity appear to affect $\mathrm{P}_{\mathrm{i}}$ uptake rates. However, other studies of natural populations and phytoplankton cultures have shown both increased uptake in light and circadian patterns in $\mathrm{P}_{\mathrm{i}}$ uptake rates (Chisholm \& Stross 1976, Reshkin \& Knauer 1979). As the uptake of $P_{i}$ is an energy-dependent process, uptake in the light may be enhanced if the cells are energy limited in the dark. In the case for phototrophs this may be the lack of light driven ener$g y$, and for heterotrophic microorganisms a possible shortage of readily available organic compounds derived from photosynthetic processes (Karl et al. 1998). As such the heterotrophic component may be more active in the light than in the dark, biasing uptake estimates for the phototrophic component. Also, uptake by the phototrophic component in the dark may occur. Furthermore, many experimental designs use only dark incubations when studying heterotrophic microorganism metabolic activities. This may confound any interpretations of the relative metabolic contribution of these 2 functional groups of microorganisms.

The microbial community composition, as determined by flow cytometry, revealed a system numerically dominated by prokaryotes, in both its heterotrophic and phototrophic components, the phototrophs consisting almost exclusively of Prochlorococcus spp. This community composition is similar to that previously reported for Stn ALOHA (Campbell et al. 1994, 1997). However, the total microbial biomass extrapolated from these data, using cell number to carbon conversion factors as reported above, always exceeded that estimated from particulate ATP presumed to represent the total living microbial biomass (Table 3 ). This may be the result of a shift in the C:ATP ratio and would be expected under P-limited conditions. It has been shown in lake studies that the C:ATP ratio may fluctuate substantially, leading to high C:ATP values during periods of P deficiency (Cavari 1976). Consequently, the conversion C:ATP would have to be adjusted upward in environments experiencing P limitation (Karl 1980). When applying the total microbial biomass estimates from flow cytometry data to obtain a C:ATP ratio for Stns ALOHA and Climax, the values were on average higher than the conventionally employed 250:1 for C:ATP (mean $380 \pm 70, \mathrm{n}=7$, range 270 to 490 ), but within the upper boundary of 500:1 modeled by Christian \& Karl (1994).

The biomass conversion factors used herein are lower than those previously applied by Campbell et al. (1994) for Prochlorococcus spp. (30 vs $53 \mathrm{fg} \mathrm{cell}^{-1}$ ), Synechococcus spp. (100 vs 175 to $250 \mathrm{fg} \mathrm{cell}^{-1}$ ) and pico-eukaryotic cells (495 vs $2100 \mathrm{fg} \mathrm{cell}^{-1}$ ). These conversion factors are based on recent revisions of biovolume: carbon estimates for these 2 groups of cyanobacteria and pico-eukaryotic cells (Chavez et al. 1996, Zubkov et al. 1998). Nevertheless, the estimated carbon biomass for Prochlorococcus spp. alone exceeded that calculated from chl a concentrations if using a C:chl a ratio of 50:1 (Christian \& Karl 1994). This may be explained by chl a not being a good predictor of Prochlorococcus biomass (Karl et al. 2000a). Furthermore, biomass estimates based on Campbell et al. (1994) g C cell $^{-1}$ values would exceed the total particulate carbon pool, the upper constraint on biomass $\mathrm{C}$, at these locations. Although beyond the scope of this study, there still appear to be discrepancies among the different approaches to estimate carbon biomass in the oligotrophic ocean.

In $\mathrm{P}_{\mathrm{i}}$ addition experiments performed in 1997, there were apparent increases in $P_{i}$ uptake rates when external $\mathrm{P}_{\mathrm{i}}$ concentrations exceeded $55 \mathrm{nM} \mathrm{P}$, and at Stn ALOHA there was also a draw down of SRP at the higher concentrations (Table 5). This net $\mathrm{P}_{\mathrm{i}}$ uptake may have been due to increased $P_{i}$ uptake rates, and possibly luxury uptake, at higher $\mathrm{P}_{\mathrm{i}}$ concentrations, generating a large enough offset between uptake and regeneration, and a sufficiently large overall $\mathrm{P}_{\mathrm{i}}$ consumption to be analytically detected after a $24 \mathrm{~h}$ incubation period. The increased uptake rates may indi- 
cate that the microbial community as a whole at these 2 stations was limited by available $\mathrm{P}$, and that the ambient concentrations may be below the threshold levels required for optimal growth and production. In P starvation experiments with Prochlococcus spp., it was suggested that the growth of these organisms was limited by $\mathrm{P}_{\mathrm{i}}$ when concentrations were in the range of 10 to $100 \mathrm{nM}$ (Parpais et al. 1996). Also, it appeared as if the tested strains were unable to remove $\mathrm{P}_{\mathrm{i}}$ at concentrations below $30 \mathrm{nM}$ (Parpais et al. 1996). Although the $\mathrm{P}_{\mathrm{i}}$ addition experiments were designed to elucidate the size of the BAP pool, the apparent rate change in $\mathrm{P}_{i}$ uptake made such an estimate impossible. Instead these data were used to estimate effects of substrate concentrations on $\mathrm{P}_{\mathrm{i}}$ uptake kinetics.

A Lineweaver-Burke transformation was employed to estimate the values of $V_{\max }$ and the half-saturation constant $K_{\mathrm{m}}$. At Stn ALOHA, $K_{\mathrm{m}}$ was $80 \pm 5 \mathrm{nM}$ and $V_{\max }$ was $8.8 \pm 0.5 \mathrm{nM} \mathrm{d}^{-1}$. For Stn Climax, $K_{\mathrm{m}}$ was about half of that observed at Stn ALOHA at $39 \pm 1 \mathrm{nM}$, but $V_{\max }$ was nearly identical at $10.1 \pm 0.1 \mathrm{nM} \mathrm{d}^{-1}$. Perry \& Eppley (1981) reported $K_{\mathrm{m}}$ values of $180 \mathrm{nM}$ for summertime samples collected in the NPSG. The lower $K_{\mathrm{m}}$ we observed here may be in response to the depletion of SRP in the upper water column over the last decade (Karl \& Tien 1997, Karl et al. 2000a). However, in the Sargasso Sea, which appears to be under severe P stress, $K_{\mathrm{m}}$ has been estimated to be as low as 5 to $10 \mathrm{nM}$ and $V_{\max } 2$-fold higher than what we observed here (Cotner et al. 1997). Although caution should be taken in using these $\mathrm{P}$ uptake kinetics as direct indications of $\mathrm{P}$ limitation, they may, when combined with other observations, add to the understanding of nutrient dynamics in the NPSG. Nevertheless, the immediate increase in uptake rates in supplemented incubations implies a microbial community pre-adapted to utilizing any available $\mathrm{P}$ above a certain concentration, indirectly indicating that ephemeral patches with higher concentrations of $\mathrm{P}$, or stochastic mixing events, may be exploited efficiently. These findings are further corroborated by the observed excess uptake of $\mathrm{P}_{\mathrm{i}}$ relative to $\left[\mathrm{NO}_{3}{ }^{-}+\mathrm{NO}_{2}{ }^{-}\right]$with episodic mixing events at Stn ALOHA and a resetting of the elemental ratio to that of Redfield stoichiometry for both particulate and dissolved matter pools (Karl 1999). The anomalously high net C:P incorporation rates (Table 4) and the particulate and dissolved matter $\mathrm{C}: \mathrm{P}$ and N:P stoichiometries (Tables $1 \& 2$ ) relative to Redfield ratios are all indicative of P-limited communities. Considering that the C:P uptake rates were based on the incorporation of ${ }^{14} \mathrm{C}$-bicarbonate (i.e., primary production) and ${ }^{32} \mathrm{P}$ incorporation by both phototrophic and heterotrophic microorganisms, this ratio must be regarded as a minimum estimation of the net uptake of $\mathrm{C}: \mathrm{P}$ in this environment.
Additionally, Cotner et al. (1997) interpreted the accumulation of dissolved organic carbon (DOC) in the Sargasso Sea as evidence of $\mathrm{P}$ rather than C limitation of heterotrophic marine bacteria. A similar trend of increasing DOC inventories in the upper water column has been observed during the last several years at Stn ALOHA. The mechanism driving this accumulation of DOC in the NPSG may well be similar to that of the Sargasso Sea and thus connected to microbial nutrient limitation such as P.

Acknowledgements. We thank the captain and crew of the RV 'Moana Wave' for support at sea. This research was supported by the National Science Foundation grants OCE9617409 and OCE 99-06820 (to D.M.K., Principal Investigator), a National Science Foundation pre-doctoral grant (awarded to A.L.T.-B.) and The American-Scandinavian Foundation, Thord-Gray's Memorial Fund (awarded to K.B.). This is SOEST contribution no. 5252 and US-JGOFS contribution no. 570.

\section{LITERATURE CITED}

Ammerman JW (1991) Role of ecto-phosphohydrolases in phosphorus regeneration in estuarine and coastal ecosystems. In: Chróst RJ (ed) Microbial enzymes in aquatic environments. Springer-Verlag, New York, p 165-186

Berman T (1988) Differential uptake of orthophosphate and organic phosphorus substrates by bacteria and algae in Lake Kinneret. J Plankton Res 10:1239-1249

Björkman K, Karl DM (1994) Bioavailability of inorganic and organic phosphorus compounds to natural assemblages of microorganisms in Hawaiian coastal waters. Mar Ecol Prog Ser 111:265-273

Bossard P, Karl DM (1986) The direct measurement of ATP and adenine nucleotide pool turnover in microorganisms: a new method for environmental assessment of metabolism, energy flux and phosphorus dynamics. J Plankton Res 8: $1-13$

Broecker WS (1974) Chemical oceanography. Harcourt Brace Jovanovich, New York

Broecker WS, Henderson GM (1998) The sequence of events surrounding Termination II and their implications for the cause of glacial-interglacial $\mathrm{CO}_{2}$ changes. Paleoceanography 13:352-364

Buat-Ménard P (1986) The role of air-sea exchange in geochemical cycling. Reidel Publishing Co, Boston

Campbell L, Vaulot D (1993) Photosynthetic picoplankton community structure in the subtropical North Pacific Ocean near Hawaii. Deep-Sea Res I 40:2043-2060

Campbell L, Nolla HA, Vaulot D (1994) The importance of Prochlorococcus to the community structure in the central North Pacific. Limnol Oceanogr 39:954-961

Campbell L, Liu H, Nolla HA, Vaulot D (1997) Annual variability of phytoplankton and bacteria in the subtropical North Pacific Ocean at Station ALOHA during the 1991-1994 ENSO event. Deep-Sea Res I 44:167-192

Capone DG, Zehr JP, Paerl HW, Bergman B, Carpenter EJ (1997) Trichodesmium, a globally significant marine cyanobacterium. Science 276:1221-1229

Carpenter EJ, Romans K (1991) Major role of the cyanobacterium Trichodesmium in nutrient cycling in the North Atlantic ocean. Science 254:1356-1358

Cavari B (1976) ATP in Lake Kinneret: indicator of microbial 
biomass or phosphorus deficiency? Limnol Oceanogr 21: 231-236

Chadwick OA, Derry LA, Vitousek PM, Huebert BJ, Hedin LO (1999) Changing sources of nutrients during four million years of ecosystem development. Nature 397:491-497

Chavez FP, Buck KR, Service SK, Newton J, Barber RT (1996) Phytoplankton variability in the central and eastern tropical Pacific. Deep-Sea Res I 43:835-870

Chisholm SW, Stross RG (1976) Phosphate uptake kinetics in Euglena gracilis (Z) (Euglenophyceae) grown in light/ dark cycles. II. Phased $\mathrm{PO}_{4}$-limited cultures. J Phycol 12: $217-222$

Christian JR, Karl DM (1994) Microbial community structure at the U.S.-Joint Global Ocean Flux Study Station ALOHA: inverse methods for estimating biochemical indicator ratios. J Geophys Res 99:14269-14276

Codispoti LA (1989) Phosphorus vs. nitrogen limitation in new and export production. In: Berger WH, Smetacek VS, Wefer G (eds) Productivity of the ocean: present and past. John Wiley \& Sons Ltd, Chichester, p 372-394

Cotner JB, Ammerman JA, Peele ER, Bentzen E (1997) Phosphorus-limited bacterioplankton growth in the Sargasso Sea. Aquat Microb Ecol 13:141-149

Cuhel RL, Jannasch HW, Taylor CD (1983) Microbial growth and macromolecular synthesis in the northwestern Atlantic Ocean. Limnol Oceanogr 28:1-18

Cullen JJ, Franks PJS, Karl DM, Longhurst A (2000) Physical influences on marine ecosystem dynamics. The Sea 12 (in press)

Dore JE, Karl DM (1996) Nitrification in the euphotic zone as a source for nitrite, nitrate, and nitrous oxide at Station ALOHA. Limnol Oceanogr 41:1619-1628

Dore JE, Houlihan T, Hebel DV, Tien G, Tupas L, Karl DM (1996) Freezing as a method of sample preservation for the analysis of dissolved nutrients in seawater. Mar Chem 53: 173-185

Duce RA (1986) The impact of atmospheric nitrogen, phosphorus, and iron species on marine biological productivity. In: Buat-Menard P (ed) The role of air-sea exchange in geochemical cycling. Reidel Publishing Co, Boston, p 497-529

Dugdale RC, Goering JJ (1967) Uptake of new and regenerated forms of nitrogen in primary productivity. Limnol Oceanogr 12:196-206

Eppley RW, Renger EH, Venrick EL, Mullin MM (1973) A study of plankton dynamics and nutrient cycling in the central North Pacific Ocean. Limnol Oceanogr 18:534-551

Falkowski PG (1997) Evolution of the nitrogen cycle and its influence on the biological sequestering of $\mathrm{CO}_{2}$ in the ocean. Nature 387:272-275

Fogg GE (1966) The extracellular products of algae. Oceanogr Mar Biol Annu Rev 4:195-212

Garside C (1982) A chemiluminescence technique for the determination of nanomolar concentrations of nitrate and nitrite in seawater. Mar Chem 11:159-167

Graham WF, Duce RA (1979) Atmospheric pathways of the phosphorus cycle. Geochim Cosmochim Acta 43: 1195-1208

Gruber N, Sarmiento JL (1997) Global patterns of marine nitrogen fixation and denitrification. Global Biogeochem Cycles 11:235-266

Harrison WG (1990) Nitrogen utilization in chlorophyll and primary production maximum layers: an analysis based on the f-ratio. Mar Ecol Prog Ser 60:85-90

Harrison WG, Harris LR (1986) Isotope-dilution and its effects on measurements of $\mathrm{N}$ and $\mathrm{P}$ uptake by oceanic microplankton. Mar Ecol Prog Ser 27:253-261
Hayward TL (1987) The nutrient distribution and primary production in the central North Pacific. Deep-Sea Res 9: 1593-1627

Hebel DV, Karl DM (2000) Seasonal, interannual and decadal variations in particulate matter concentrations and composition in the subtropical North Pacific Ocean. Deep-Sea Res II (in press)

Herbland A (1984) Phosphate uptake in the euphotic layer of the Equatorial Atlantic Ocean. Methodological observations and ecological significance. Oceanogr Trop 19:24-40

Holm-Hansen O (1973) Determination of total microbial biomass by measurement of adenosine triphosphate. In: Stevenson LH, Colwell RR (eds) Estuarine microbial ecology. University of South Carolina Press, Columbia, p 73-89

Jackson GA, Williams PM (1985) Importance of dissolved organic nitrogen and phosphorus to biological nutrient cycling. Deep-Sea Res 32:223-235

Johnson DL (1971) Simultaneous determination of arsenate and phosphate in natural waters. Environ Sci Technol 5: 411-414

Karl DM (1980) Cellular nucleotide measurements and applications in microbial ecology. Microbiol Rev 44:739-796

Karl DM (1993) Adenosine triphosphate (ATP) and total adenine nucleotide (TAN) pool turnover rates as measures of energy flux and specific growth rate in natural populations of microorganisms. In: Kemp PF, Sherr BF, Sherr EB, Cole JJ (eds) Handbook of methods in aquatic microbial ecology. Lewis Publishers, Boca Raton, p 483-494

Karl DM (1999) A sea of change: biogeochemical variability in the North Pacific Subtropical Gyre. Ecosystems 2:181-214

Karl DM, Bossard P (1985) Measurement and significance of ATP and adenine nucleotide pool turnover in microbial cells and environmental samples. J Microbiol Methods 3: 125-139

Karl DM, Holm-Hansen O (1978) Methodology and measurement of adenylate energy charge ratios in environmental samples. Mar Biol 48:185-197

Karl DM, Lukas R (1996) The Hawaii Ocean Time-series (HOT) program: background, rationale and field implementation. Deep-Sea Res II 43:129-156

Karl DM, Tien G (1992) MAGIC: a sensitive and precise method for measuring dissolved phosphorus in aquatic environments. Limnol Oceanogr 37:105-116

Karl DM, Tien G (1997) Temporal variability in dissolved phosphorus concentration in the subtropical North Pacific Ocean. Mar Chem 56:77-96

Karl DM, Yanagi K (1997) Partial characterization of the dissolved organic phosphorus pool in the oligotrophic North Pacific Ocean. Limnol Oceanogr 42:1398-1405

Karl DM, Jones DR, Novitsky JA, Winn CD, Bossard P (1987) Specific growth rates of natural microbial communities measured by adenine nucleotide pool turnover. J Microbiol Methods 6:221-235

Karl DM, Dore JE, Hebel DV, Winn CD (1991) Procedures for particulate carbon, nitrogen, phosphorus and total mass analyses used in the US-JGOFS Hawaii Ocean Timeseries program. In: Hurd DC, Spencer DW (eds) Marine particles: analysis and characterization. American Geophysical Union, Washington, DC, p 71-77

Karl DM, Letelier R, Hebel DV, Bird DF, Winn CD (1992) Trichodesmium blooms and nitrogen in the North Pacific Gyre. In: Carpenter EJ, Capone DG, Rueter JG (eds) Marine pelagic cyanobacteria: Trichodesmium and other diazotrophs. Kluwer Academic Publishers, Dordrecht, p 219-237

Karl DM, Letelier R, Hebel D, Tupas L, Dore J, Christian J, Winn C (1995) Ecosystem changes in the North Pacific 
subtropical gyre attributed to the 1991-92 El Niño. Nature 373:230-234

Karl DM, Christian JR, Dore JE, Hebel DV, Letelier RM, Tupas LM, Winn CD (1996) Seasonal and interannual variability in primary production and particle flux at Station ALOHA. Deep-Sea Res II 43:539-568

Karl D, Letelier R, Tupas L, Dore J, Christian J, Hebel D (1997) The role of nitrogen fixation in biochemical cycling in the subtropical North Pacific Ocean. Nature 388:533-538

Karl DM, Hebel DV, Björkman K, Letelier RM (1998) The role of dissolved organic matter release in the productivity of the oligotrophic North Pacific Ocean. Limnol Oceanogr 43:1270-1286

Karl DM, Bidigare RR, Letelier RM (2000a) Long-term changes in plankton community structure and productivity in the subtropical North Pacific Ocean: the domain shift hypothesis. Deep-Sea Res II (in press)

Karl DM, Björkman KM, Dore JE, Fujieki L, Hebel DV, Houlihan T, Letelier RM, Tupas LM (2000b) Ecological nitrogen-to-phosphorus stoichiometry at Station ALOHA. Deep-Sea Res II (in press)

Krom MD, Kress N, Brenner S (1991) Phosphorus limitation of primary productivity in the eastern Mediterranean Sea. Limnol Oceanogr 36:424-432

Kuentzler EJ (1970) Dissolved organic phosphorus excretion by marine phytoplankton. J Phycol 6:7-13

Letelier RM, Karl DM (1996) The importance of Trichodesmium spp. in the productivity of the subtropical North Pacific Ocean. Mar Ecol Prog Ser 133:263-273

Letelier RM, Karl DM (1998) Trichodesmium spp. physiology and nutrient fluxes in the North Pacific subtropical gyre. Aquat Microb Ecol 15:265-276

Liebig J (1842) Chemistry and its application in agriculture and physiology. Taylor and Walton, London

McCarthy JJ, Carpenter EJ (1983) Nitrogen cycling in nearsurface waters of the open ocean. In: Carpenter EJ, Capone DS (eds) Nitrogen in the marine environment. Academic Press, New York, p 487-512

Menzel DW, Corwin N (1965) The measurement of total phosphorus in seawater based on liberation of organically bound fractions by persulfate oxidation. Limnol Oceanogr 10:280-282

Michaels AF, Olson D, Sarmiento JL, Ammerman JW, Fanning KA, Jahnke R, Knap AH, Lipschultz F, Prospero JM (1996) Inputs, losses and transformations of nitrogen and phosphorus in the pelagic North Atlantic Ocean. Biogeochemistry 35:181-226

Mitsui A, Kumazawa S, Takahashi A, Ikemoto H, Cao S, Arai $\mathrm{T}$ (1986) Strategy by which nitrogen-fixing unicellular cyanobacteria grow phototrophically. Nature 323:720-722

Monger BC, Landry MR (1993) Flow cytometric analysis of marine bacteria with Hoechst 33342. Appl Environ Microbiol 59:905-911

Orrett K, Karl DM (1987) Dissolved organic phosphorus production in surface seawaters. Limnol Oceanogr 32:383-395

Paerl HW (1993) Emerging role of atmospheric nitrogen deposition in coastal eutrophication: biogeochemical and trophic perspectives. Can J Fish Aquat Sci 50:2254-2269

Parpais J, Marie D, Partensky F, Morin P, Vaulot D (1996) Effect of phosphorus starvation on the cell cycle of the photosynthetic prokaryote Prochlorococcus spp. Mar Ecol Prog Ser 132:265-274

Perry MJ (1976) Phosphate utilization by an oceanic diatom in phosphate-limited chemostat culture and in the oligotrophic waters of the central North Pacific. Limnol

Editorial responsibility: Farooq Azam,

La Jolla, California, USA
Oceanogr 21:88-107

Perry MJ, Eppley RW (1981) Phosphate uptake by phytoplankton in the central North Pacific Ocean. Deep-Sea Res 28A:39-49

Proctor LM, Fuhrman JA (1990) Viral mortality of marine bacteria and cyanobacteria. Nature 343:60-62

Redfield AC (1958) The biological control of chemical factors in the environment. Am Sci 46:205-222

Redfield AC, Ketchum BH, Richards FA (1963) The influence of organisms on the composition of seawater. In: Hill MN (ed) The sea. Interscience, New York, p 26-77

Reshkin SJ, Knauer GA (1979) Light stimulation of phosphate uptake in natural assemblages of phytoplankton. Limnol Oceanogr 24:1121-1124

Ryther JH, Dunstan WH (1971) N, P and eutrophication in the coastal marine environment. Science 171:1008-1013

Schindler DW (1977) Evolution of P limitation in lakes. Science 195:260-262

Sharp JH (1977) Excretion of organic matter by marine phytoplankton: do healthy cells do it? Limnol Oceanogr 22: 381-397

Simidi U, Tsukamoto K (1985) Habitat segregation and biochemical activities of marine members of the family Vibrionaceae. Appl Environ Microbiol 50:781-790

Siuda W, Güde H (1994) A comparative study on 5'-nucleotidase (5'-nase) and alkaline phosphatase (APA) activities in two lakes. Arch Hydrobiol 131:211-229

Smith SV (1984) P versus N limitation in marine environment. Limnol Oceanogr 29:1149-1160

Sorokin YI (1985) P metabolism in planktonic communities of the eastern tropical Pacific Ocean. Mar Ecol Prog Ser 27: 87-97

Tamminen T (1989) Dissolved organic phosphorus regeneration by bacterioplankton: 5'-nucleotidase activity and subsequent phosphate uptake in a mesocosm experiment. Mar Ecol Prog Ser 58:89-100

Tarapchak SJ, Moll RA (1990) Phosphorus sources for phytoplankton and bacteria in Lake Michigan. J Plankton Res 12:743-758

Thomas WH (1966) Surface nitrogenous nutrients and phytoplankton in the northeastern Pacific Ocean. Limnol Oceanogr 11:393-400

Thomson-Bulldis A, Karl DM (1998) Applications of a novel method for phosphorus determinations in the oligotrophic North Pacific Ocean. Limnol Oceanogr 43:1565-1577

Tyrell T (1999) The relative influence of nitrogen to phosphorus on oceanic primary production. Nature 400:525-531

Venrick EL, McGowan JA, Cayan DR, Hayward TL (1987) Climate and chlorophyll a: long-term trends in the Central North Pacific Ocean. Science 238:70-72

Wood AM, van Valen LM (1990) Paradox lost? On release of energy-rich compounds by phytoplankton. Mar Microb Food Webs 4:103-116

Wu J, Sunda W, Boyle EA, Karl DM (2000) Phosphate depletion in the Western Atlantic Ocean. Science (in press)

Zehr JP, Mellon MT, Zani S (1998) New nitrogen fixing microorganisms detected in oligotrophic ocean by amplification of nitrogenase (nif $\mathrm{H})$ genes. Appl Environ Microbiol 64:3444-3450

Zohary T, Robarts RD (1998) Experimental study of microbial $\mathrm{P}$ limitation in the eastern Mediterranean. Limnol Oceanogr 43:387-395

Zubkov MV, Sleigh MA, Tarran GA, Burkill PH, Leakey RJG (1998) Picoplankton community structure on an Atlantic transect from $50^{\circ} \mathrm{N}$ to $50^{\circ} \mathrm{S}$. Deep-Sea Res I 45:1339-1355

Submitted: July 27, 1999; Accepted: May 30, 2000

Proofs received from author(s): July 28, 2000 